\title{
A decade of geophysical surveying in Greenland
}

\section{Thorning}

\begin{abstract}
A review is given of aeromagnetic, radiometric, seismic and gravimetric surveys over Greenland and adjacent offshore waters carried out during the decade 1975-85. The determination by aeromagnetic surveys of major boundaries in the Precambrian craton in ice-free areas and under the Inland Ice is discussed.
\end{abstract}

\section{Introduction}

The last decade has seen an increasing use of geophysical methods in Greenland for solving geological problems. This is partly due to the general trend in earth sciences towards quantification of observations, but it also reflects the increased interest in areas which cannot be investigated by more traditional geological methods, primarily continental shelf areas around Greenland and the huge region covered by the Inland Ice. Another trend which has played an important role for this development is the necessity to follow up in depth the geological indications which can be observed on the surface, be it regional structural trends or smaller economically interesting features. Several geophysical methods have been applied over the years. This note briefly reviews all major geophysical surveys to give an impression of the scope of activities within this field, and discusses some examples of interesting geological features in the light of data from aeromagnetic surveys. Figures in brackets refer to the areas outlined in fig. 1 , where only the aeromagnetic surveys are shown.

\section{Magnetic surveys}

The regionally most complete magnetic surveys are those acquired by POGO and MAGSAT satellites. Although lacking in detail these data provide information on large scale crustal structures under Greenland. Langel \& Thorning (1982a,b) have analyzed the data from earlier POGO satellites, and in fig. 2 a new satellite magnetic anomaly map based on MAGSAT data, taken from Thorning \& Langel (unpublished), is shown to illustrate this field of geophysics. Ongoing cooperation between GGU and NASA is concerned with the modelling of crustal structures apparent in this map.

The first systematic aeromagnetic survey over Precambrian terrains in Greenland was flown in 1967 and 1968 by Finprospecting Ky for Kryolitselskabet Øresund A/S and covered most of the onshore areas between Kap Farvel and Disko Bugt (fig. 1a, 1). The original data were hand contoured and contain severe levelling errors, but the copies of the contour maps held by GGU (in closed file) have been digitized, and an attempt is now being made at GGU to produce better maps by digital filtering.

Over the years Finprospecting Ky, again for the Kryolitselskabet Øresund A/S, has carried out a number of more detailed mineral exploration aeromagnetic and electromagnetic surveys, as well as several ground geophysical surveys in central West Greenland. GGU holds copies of these data, but they are in closed file, and will not be discussed in this note. 

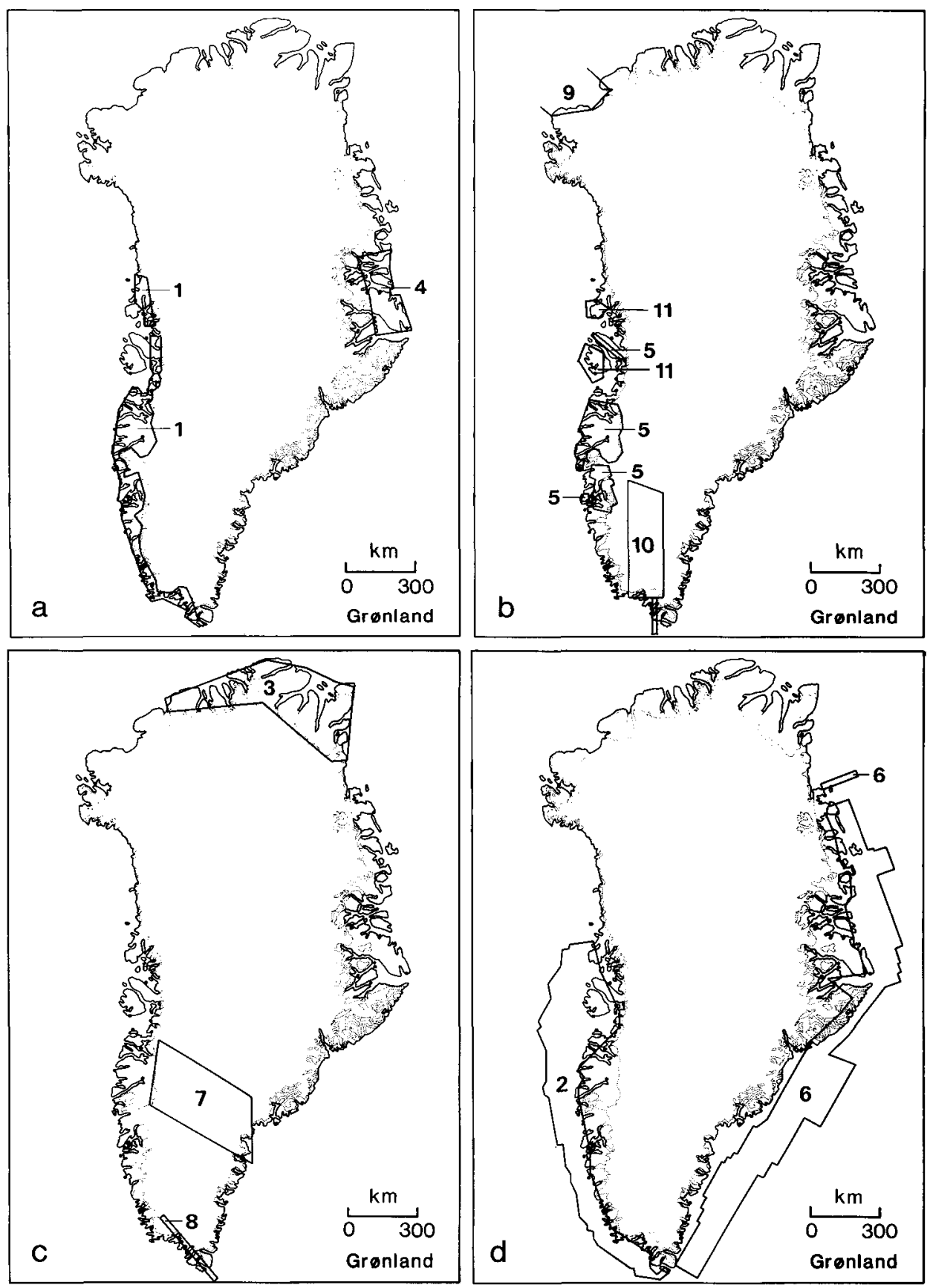

Fig. 1. Index map showing aeromagnetic surveys mentioned in the text. Explanation on facing page. 


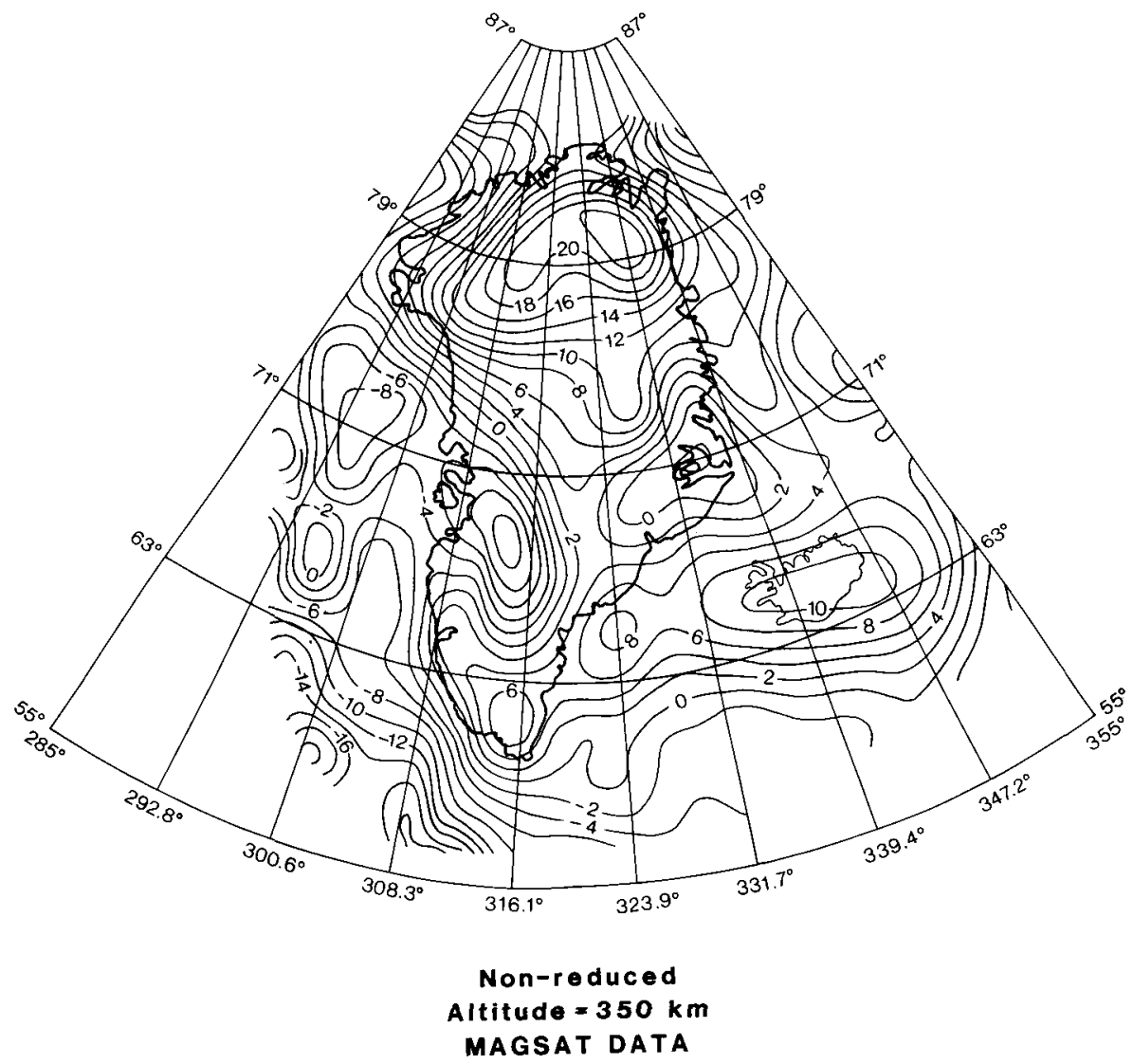

Fig. 2. Satellite magnetic anomaly map of Greenland (from Thorning \& Langel, unpublished compilation).

In 1975 and 1976 GGU carried out survey operations in southern and central West Greenland (fig. 1b, 5) (Thorning, 1976, 1977) covering major parts of the Precambrian terrains between $64^{\circ}$ and $68^{\circ} 15^{\prime} \mathrm{N}$. These surveys have recently been dicussed in Thorning (1984).

In 1983, through cooperation with Canadian institutions (The Geological Survey of Canada (GSC), and The National Aeronautical Establishment (NAE)), it was possible to obtain high quality total field and gradient data over part of the Inland Ice between Søndre Strømfjord and Angmagssalik (fig. 1c, 7) (Thorning et al., 1984). The purpose of this survey was research into the linking of geological units of the east and west coasts. In a small oper-

Fig. 1 cont. Explanation to figure.

1. Kryolitselskabet Øresund A/S 1967-68

2. Tenneco Oil, California Oil Co. 1970

3. Greenarctic Consortium 1971

4. GGU 1974

5. GGU $1975-76$
6. GGU 1979

7. GICAS (GGU/NAE/GSC) 1983

8. GICAS (GGU/NAE/GSC) 1984

9. NAE/GSC 1982-84

10. GGU/NAE/GSC 1985

11. Greenex 1985 
ation in 1984 a few reconnaissance lines were flown in South Greenland in preparation for the planning of further operations in South Greenland (fig. 1c, 8) (Thorning et al., 1985) carried out in 1985 (fig. 1c, 10), and the same Canadian group has flown a survey over the Kane Basin and Nares Strait between Canada and Greenland in the period 1982-1984 (fig. 1b, 9).

In 1971 Grumman Ecosystems Corporation carried out a regional aeromagnetic survey of North Greenland and certain nearby areas for Greenarctic Consortium, who held an exploration concession for the area (fig. 1c, 3). This survey ran into serious difficulties due to the very inaccurate maps of the area at that time, and for that reason the data have so far not been compiled into maps. The data are deposited with GGU in closed file, and will be compiled and reprocessed when better maps become available. At present the flight paths are being reconstructed and plotted on new orthophoto maps prepared by the Geodetic Institute.

The search for new sources of energy has been the driving force behind several geophysical surveys in Greenland. In 1970 Geoterrex Ltd. of Canada flew two surveys offshore West Greenland, one for Tenneco Oil and one for California Oil Company of Denmark. The two surveys covered approximately the same area (fig. 1d, 2), but while one of the surveys used equal spacing of all lines, the other was flown in bands of more closely spaced lines. Some of these data are now in open file and are available as contour maps. The data were included in the compilation of aeromagnetic data from northern Canada by McGrath \& Fraser (1981).

GGU's first aeromagnetic surveys developed from the airborne radiometric surveys in East Greenland (see below). In 1974 an area in central East Greenland was surveyed (fig. 1a, 4) (H. C. Larsen, 1975), and this survey became of particular interest when Jameson Land was opened for oil exploration.

In 1979 a major aeromagnetic survey was flown for GGU by Aero Service of Houston, USA, offshore East Greenland (fig. 1d, 6) in connection with an energy programme for oil exploration (Thorning, 1978; Larsen \& Thorning, 1979, 1980). It covered most of the shelf area from $60^{\circ}$ to $72^{\circ} \mathrm{N}$ with high quality data, which together with later seismic work has yielded many excellent results.

\section{Radiometry}

In accordance with Danish law radioactive minerals are exempted from concessions given to commercial companies, and thus the responsibility for exploration for these minerals rests with GGU.

GGU started airborne radiometric operations in 1971 in the Scoresby Sund region, East Greenland (Nielsen, 1972), and these were continued in 1973 and 1974 (Nielsen \& Larsen, 1974; Nielsen \& Steenfelt, 1975) when the airborne equipment also included instrumentation for magnetic field measurement. The aeroradiometric measurements were continued in West Greenland in 1975 and 1976 (Secher, 1976, 1977), and in 1979 a uranium exploration programme in South Greenland included an airborne radiometric survey (Armour-Brown et al., 1980).

\section{Seismic investigations}

Several marine geophysical surveys have taken place in the waters around Greenland in connection with scientific research in different institutions, and in the waters off central and 
southern West Greenland in relation to oil exploration concessions in this area (e.g. Henderson, 1976). Most of GGU's activities in this field are also related to the search for energy sources and started in 1972 in the area around Disko and Nûgssuaq (see Denham, 1974 which also contains references to earlier work in the area mainly carried out by Canadian institutions). These activities were supported by a ship equipped with a seismic reflection system and magnetometer. Similar work was carried out in 1974 and 1975 in some fjords in West Greenland (B. Larsen, 1976) and offshore South-East Greenland. In 1978 a shallow marine geophysical survey was carried out offshore West Greenland between $64^{\circ}$ and $70^{\circ} \mathrm{N}$ (Brett \& Zarudzki, 1979; Zarudzki, 1980), and the same equipment was used in 1979 on the East Greenland shelf between $60^{\circ}$ and $70^{\circ} \mathrm{N}$ (B. Larsen, 1980). In 1980-1982 multichannel seismic reflection, magnetic and gravity surveys were carried out by contractors for GGU over various areas of the East Greenland shelf and Scoresby Sund (Andersen et al., 1981; Larsen \& Andersen, 1982; H. C. Larsen, 1983).

\section{Gravimetric investigations}

A programme of regional gravity measurements has been carried out by the Geodetic Institute (see e.g. Kejlsø, 1958; Saxov, 1958; Weng, 1980; Forsberg, 1981). All gravity data in Greenland are held in the Geodetic Institute's data base.

\section{Detailed studies}

The activities mentioned so far have mostly been of the regional type. Arising from these surveys, or from more narrowly defined geological problems, a number of detailed geophysical investigations have been carried out by GGU, e.g. seismic studies on Disko and Nûgssuaq (Sharma, 1973; Elder, 1975), follow-up ground geophysical work on regional or local aeromagnetic anomalies (Thorning et al., 1978; Thorning, 1979; Mielby \& Svendsen, 1979; Secher \& Thorning, 1982), geophysical investigations in connection with mineral exploration programmes (Ghisler \& Sharma, 1969; Thorning, 1983; Nyegaard \& Thorning, 1983; Armour-Brown et al., 1984; Thorning \& Boserup, 1985), and glaciological problems (Thorning, 1985). Finally, a great deal of palaeomagnetic investigations have been carried out in all parts of Greenland (see e.g. Marcussen \& Abrahamsen, 1983 and Beckman, 1979 for a fairly complete list of references).

\section{Examples from aeromagnetic surveys}

Although not complete this listing of geophysical surveys and activities carried out in Greenland between 1967 and 1984 demonstrates the wide range of geophysical methods employed in Greenland over the last decade. These surveys have added a wealth of information to our knowledge of the geoloy of Greenland. It is clearly impossible to describe results of all these surveys in detail. In the following a few selected examples from aeromagnetic surveys will be discussed in more detail, and some new data of interest will be presented for the first time.

A large part of Greenland is made up of exposed rocks of Precambrian age, and in other areas Precambrian rocks are the most likely candidate for the basement underlying sedimentary sequences and the Inland Ice. Thus, it is of considerable interest to understand the 

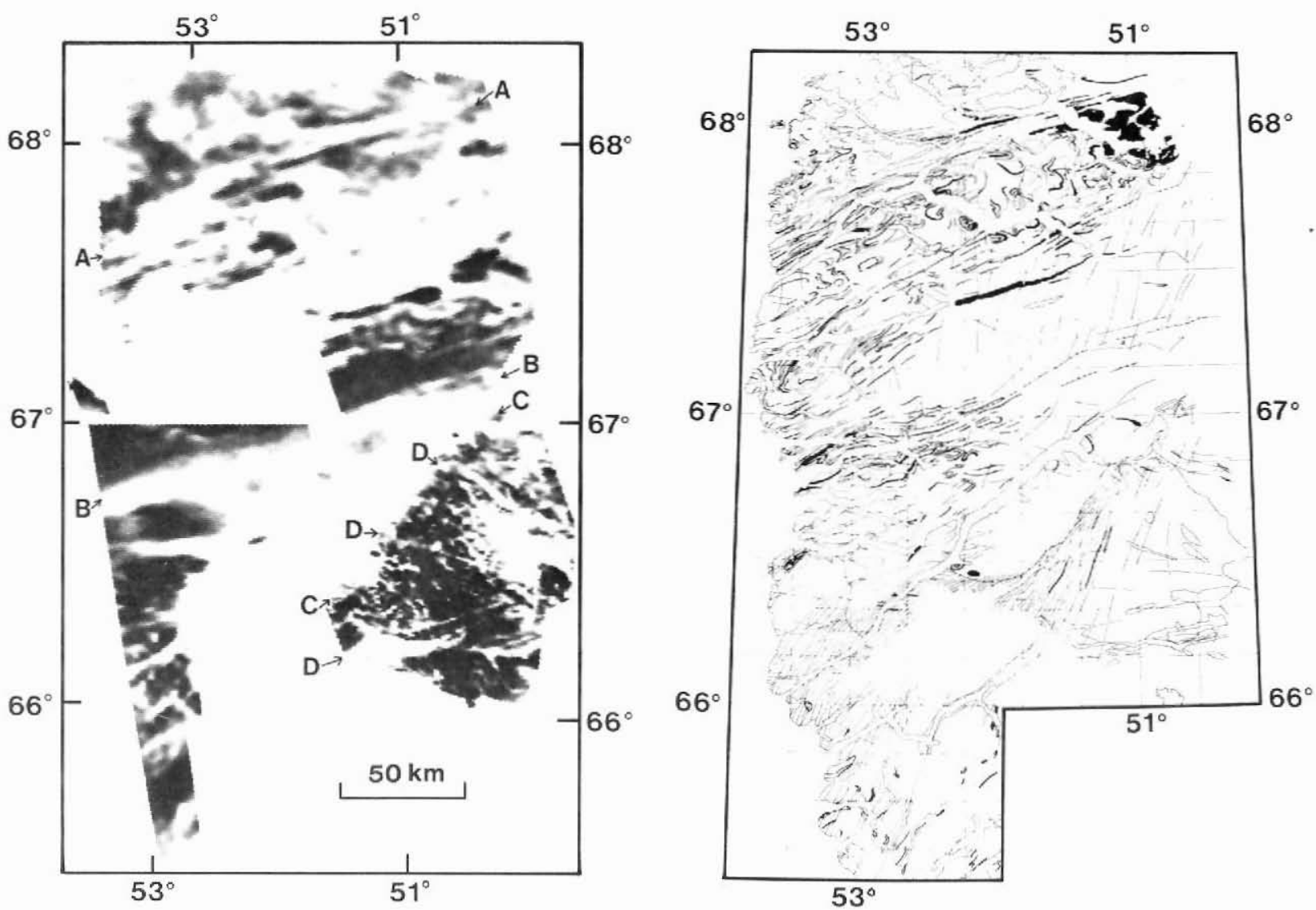

Fig. 3a. Grey-tone maps of three survey areas in central West Greenland (see Thorning, 1984). The map has been produced from GGU's base of gridded data by Martti Korhonen, using a linear scale of grey-tones (dark tones indicate high magnetic susceptibility) as a first test plot of data from Greenland of this type, made on an Optronix plotter. Graphic Arts Laboratory. Technical Research Centre of Finland. A: Nordre Strømfjord shear belt. B: boundary between Ikertôq and Isortoq complexes, C: boundary between Nagssugtoqidian mobile belt and Archaean craton. D: linear minima. b. Sketch map of geology of corresponding area. After GGU's 1:500 000 geological map sheets. 


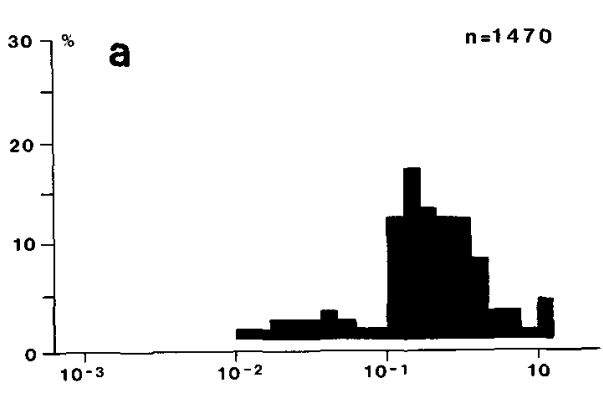

SUSCEPTIBILITY

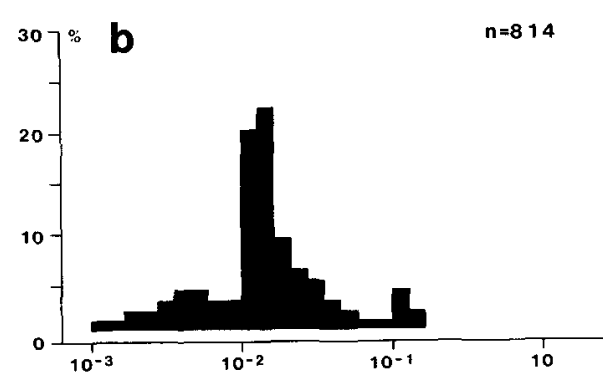

SUSCEPTIBILITY

Fig. 4. Magnetic susceptibilities (cgs) of gneisses in granulite facies (a) and amphibolite facies (b).

magnetic signature of the structures and lithologies of the Precambrian rocks. In this section some examples will be shown based on data from surveys (1), (2), (5), (6), and (7) (fig. 1).

The surveys of southern and central West Greenland, recently discussed by Thorning (1984), can be taken as a starting point. In fig. 3, three survey areas have been plotted as grey-tone maps, and several key features for the understanding of the geology of this area can be seen very clearly: the Nordre Strømfjord shear belt (A, fig. 3a) is seen as a linear minimum reaching from the coast to the Inland Ice. Further south, the band of magnetic rock north of the boundary between the Ikertôq and Isortoq complexes (B), and the boundary between the Nagssugtoqidian mobile belt and the Archaean craton are obvious (C). The grey-tone map reveals many other details about the geology. There are several linear minima which may be indicative of fault or shear structures (D). Similar structures have been examined in South Greenland (Nyegaard \& Thorning, 1983; Thorning \& Boserup, 1985), where the minima are shown to be caused by the destruction of magnetite in fault zones. Such fault zones seem to be fairly common in most of southern and central West Greenland and in South Greenland, and are even better revealed by a combination of magnetic and very low frequency electromagnetic (VLF) survey methods (Nyegaard \& Thorning, 1983).

Variations in metamorphic facies are also reflected in the aeromagnetic data, not only in connection with the partly tectonically determined boundaries between the Nagssugtoqidian mobile belt and Archaean craton and between the various units in the Nagssugtoqidian mobile belt, but also where the boundary between granulite and amphibolite facies rocks is a result of differential erosion or progressive or retrogressive metamorphism (see Thorning, 1984 for detailed discussion). In fig. 4 some new data of interest for this subject are shown. The two histograms give the distribution of field measurements of magnetic susceptibilities in an area between $64^{\circ}$ and $69^{\circ} \mathrm{N}$ of various gneiss varieties in amphibolite and granulite facies, and clearly demonstrate the difference in magnetic properties. Further sampling work is planned for 1985 in order to gain a better understanding of the relationship between magnetic properties and metamorphic facies.

Based on this knowledge it is possible to follow some fundamental geological boundaries across Greenland. Using the regional map by McGrath \& Fraser (1981), the approximate position of the southern limit of the Isortoq complex can be inferred offshore West Greenland since it appears that the granulite facies rocks dominate further south. The resolution of the offshore data does not allow the Nordre Strømfjord shear belt to be followed offshore 


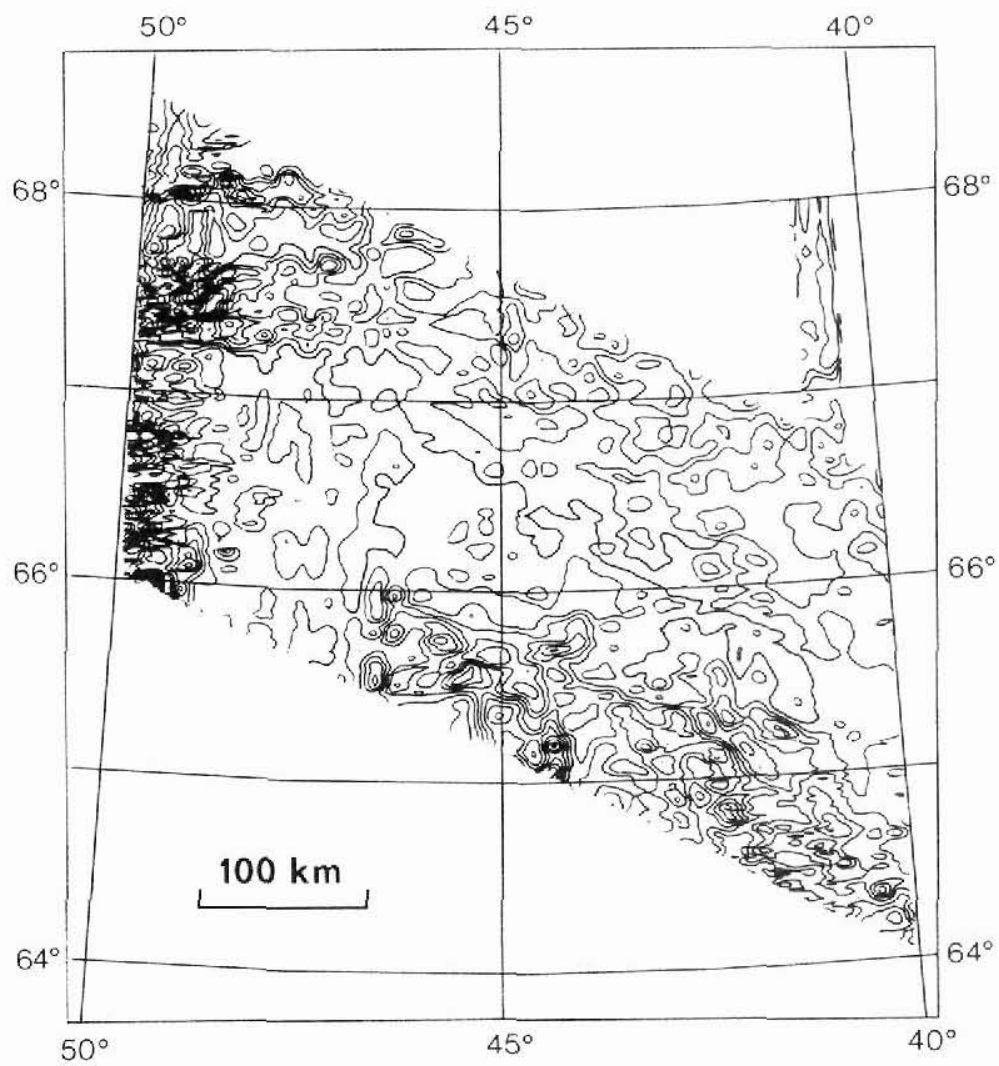

Fig. 5. Contour map of magnetic total field relative to IGRF 80 up-dated to 1983, based on preliminary data from the GICAS 1983 survey; only roughly corrected for diurnal variation. Area 7 of fig. 1 .

(fig. 6). To the east, the data from the Greenland Ice Cap Aeromagnetic Survey (GICAS Thorning et al., 1984) make it possible to follow the same boundaries under the ice. In fig. 5 a contour map of the magnetic total field is shown, and although the map is preliminary and only roughly corrected for diurnal variations, the contour pattern alone reveals several boundaries which are plotted in fig. 6 . When the final data from this survey become available, filtering and upward and downward continuation of the magnetic data will further refine the position of the boundaries, especially in areas where it is still uncertain (question marks in fig. 6). The magnetically determined boundary between the Archaean and the Nagssugtoqidian in East Greenland corresponds well with the geology mapped there, and the aeromagnetic data from offshore East Greenland allow this boundary to be followed part of the way to the edge of the continental shelf (fig. 6). A few other boundaries or structures, some of them as yet of unknown nature, have been indicated under the Inland Ice. It must be stressed that the interpretation of the GICAS data is preliminary and may have to be changed when the final data become available for analysis. 


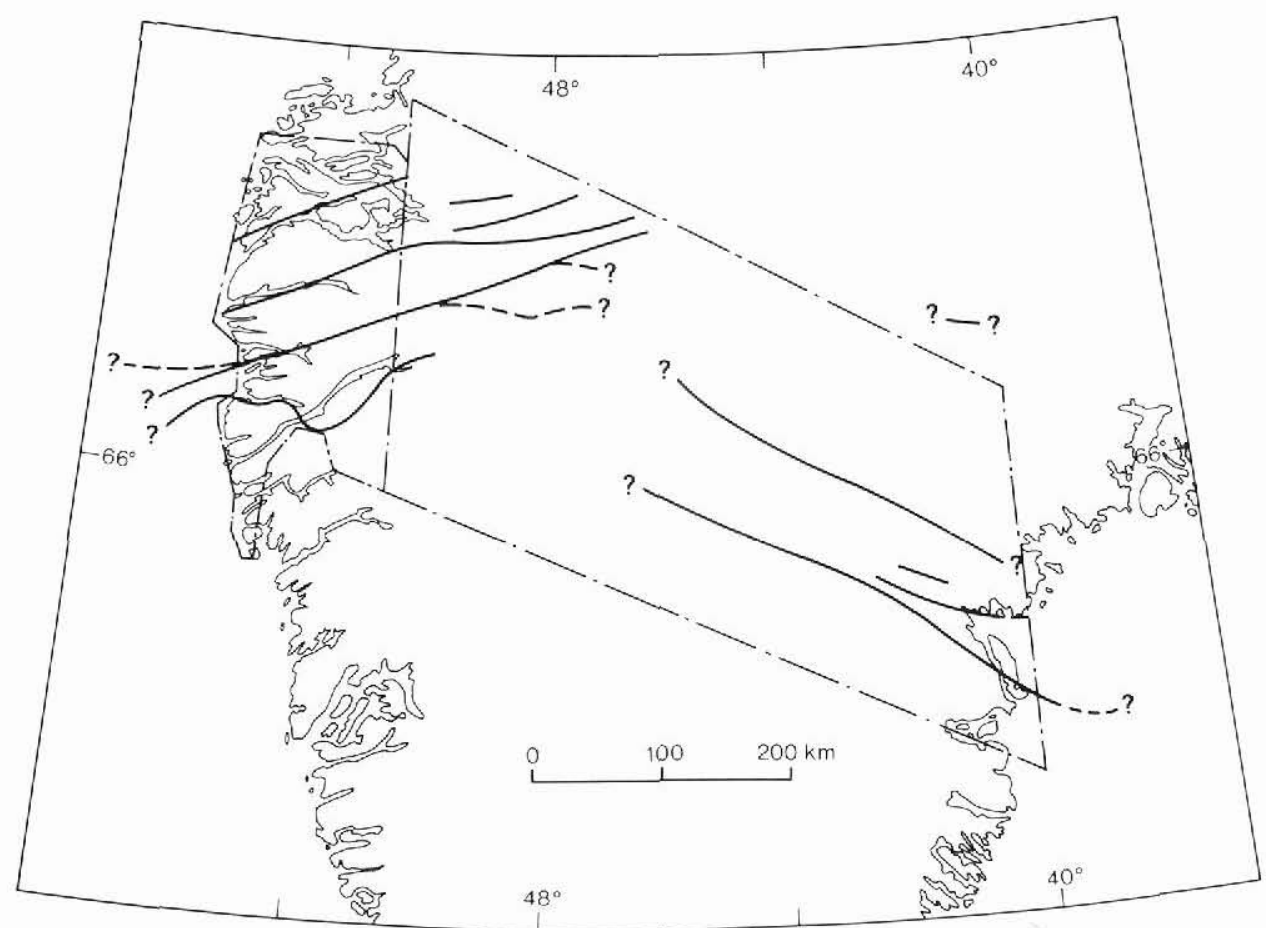

Fig. 6. Approximate positions of lineaments as revealed by aeromagnetic data shown in figs 3 and 5 .

\section{Future work}

In this note it has been attempted to give an impression of the scope of geophysical activities in Greenland, and some new results from recent aeromagnetic surveys have been outlined. In the next few years a similar level of activities seems likely: industry-based seismic work in connection with oil exploration in Jameson Land, and new airborne geophysical surveying in the Disko - Nûgssuaq area in connection with mineral exploration (carried out by Grecnex A/S in 1985, fig. 1c, 11). GGU's own activities involve further: sampling for petrophysical investigations in relation to metamorphic facies in West Greenland; palaeomagnetic sampling in North Greenland; further detailed ground geophysical investigation in relation to mineral exploration programmes; reprocessing of seismic data from offshore West Greenland, and of aeromagnetic data from North Greenland and offshore East Greenland; airborne operations in continuation of the Greenland Ice Cap Aeromagnetic Survey focused on the region of the Inland Ice south of the area surveyed in 1983; possibly more detailed aeromagnetic and electromagnetic surveys of selected areas, and application of geophysical methods to glaciological problems. There is thus good reason to expect that the next decade will be equally fruitful, hopefully more so through an even better integration of geological and geophysical methods. 


\section{References}

Andersen, M. S., Larsen, H. C., Risum, J. B. \& Thorning, L. 1981: Geophysical activities offshore East Greenland - Project NAD. Rapp. Grønlands geol. Unders. 105, 56-60.

Armour-Brown, A., Tukiainen, T. \& Wallin, B. 1980: The South Greenland uranium exploration project. Rapp. Grønlands geol. Unders. 100, 83-86.

Armour-Brown, A. Tukiainen, T., Nyegaard, P. \& Wallin, B. 1984: The South Greenland regional uranium exploration programme. Final report of progress 1980-1983. Copenhagen: Geol. Surv. Greenland.

Beckman, G. E. J. 1979: A view of Nagssugtoqidian palaeomagnetism. Rapp. Grønlands geol. Unders. 89, 115-124.

Brett, C. P. \& Zarudzki, E. F. K. 1979: Project WESTMAR - a shallow marine geophysical survey on the West Greenland continental shelf. Rapp. Grønlands geol. Unders. 87, $29 \mathrm{pp}$.

Denham, L. R. 1974: Offshore geology of northern West Greenland $\left(69^{\circ}\right.$ to $\left.75^{\circ} \mathrm{N}\right)$. Rapp. Grønlands geol. Unders. 63, $24 \mathrm{pp}$.

Elder, J. W. 1975: A seismic and gravity study of the western part of the Cretaceous - Tertiary sedimentary basin of central West Greenland. Rapp. Grønlands geol. Unders. 69, 5-9.

Forsberg, R. 1981: Preliminary Bouguer anomalies of North-East Greenland. Rapp. Grønlands geol. Unders. 106, 105-107.

Ghisler, M. \& Sharma, P. V. 1969: On the applicability of magnetic prospecting for chromite in the Fiskenæsset region, West Greenland. Rapp. Grønlands geol. Unders. 26, 25 pp.

Henderson, G. 1976: Development in petroleum exploration offshore West Greenland during 1975. Rapp. Grønlands geol. Unders. 80, 29-31.

Kejlsø, E. 1958: Gravity measurements in Western Greenland 1950-52. Geod. Inst. Skr. (3), 27, 69 pp.

Langel, R. A. \& Thorning, L. 1982a: A satellite magnetic anomaly map of Greenland. Geophys. J. roy. astr. Soc. 71, 599-612.

Langel, R. A. \& Thorning, L. 1982b: Satellite magnetic field over the Nares Strait region. In Dawes, P. R. \& Kerr, J. W. (edit.) Nares Strait and the drift of Greenland: a conflict in plate tectonics. Meddr Grønland Geosci. 8, 291-293.

Larsen, B. 1976: Investigations of the sediment thickness in Søndre Strømfjord, West Greenland. Rapp. Grønlands geol. Unders. 85, 47-48.

Larsen, B. 1980: A marine geophysical survey of the East Greenland continental shelf between latitudes $60^{\circ}$ and $70^{\circ} \mathrm{N}$ - Project DANA 79. Rapp. Grønlands geol. Unders. 100, 94-98.

Larsen, H. C. 1975: Aeromagnetic investigations in East Greenland. Rapp. Grønlands geol. Unders. $75,88-91$.

Larsen, H. C. 1983: Marine geophysical investigations offshore East Greenland. Rapp. Grønlands geol. Unders. 115, 93-100.

Larsen, H. C. \& Andersen, M. S. 1982: Marine geophysical investigations offshore East Greenland. Rapp. Grønlands geol. Unders. 110, 81-86.

Larsen, H. C. \& Thorning, L. 1979: Project EASTMAR: planning of an aeromagnetic survey off East Greenland. Rapp. Grønlands geol. Unders. 95, 93-96.

Larsen, H. C. \& Thorning, L. 1980: Project EASTMAR: acquisition of high sensitivity aeromagnetic data off East Greenland. Rapp. Grønlands geol. Unders. 100, 91-94.

Marcussen, C. \& Abrahamsen, N. 1983: Palaeomagnetism of the Proterozoic Zig-Zag Dal Basalt and the Midsommers $\emptyset$ Dolerites, eastern North Greenland. Geophys. J. roy. astr. Soc. 73, 367-387.

McGrath, P. H. \& Fraser, I. 1981: Aeromagnetic map of Arctic Canada. Geological Survey of Canada.

Mielby, B. S. \& Svendsen, F. 1975: Ground magnetic investigations of selected aeromagnetic anomalies in southern West Greenland. Rapp. Gronlands geol. Unders. 95, 63-66.

Nielsen, B. L. 1972: Aeroradiometric survey in the Scoresby Sund region, East Greenland. Rapp. Grønlands geol. Unders. 45, 42-43. 
Nielsen, B. L. \& Larsen, H. C. 1974: Airborne geophysical survey in central East Greenland. Rapp. Grønlands geol. Unders. 65, 73-76.

Nielsen, B. L. \& Steenfelt, A. 1975: Prospecting for uranium in central East Greenland. Rapp. Grønlands geol. Unders. 75, 107-110.

Nyegaard, P. \& Thorning, L. 1983: Geophysical and geological field work on fault structures at the Igaliko peninsula, South Greenland. Rapp. Grønlands geol. Unders. 115, 75-79.

Saxov, S. 1958: Gravity in western Greenland from $66^{\circ} \mathrm{N}$ to $69^{\circ} \mathrm{N}$. Geod. Inst. Skr. (3), 29, $34 \mathrm{pp}$.

Secher, K. 1976: Airborne radiometric survey between $66^{\circ}$ and $69^{\circ} \mathrm{N}$, southern and central West Greenland. Rapp. Gronlands geol. Unders. 80, 65-67.

Secher, K. 1977: Airborne radiometric survey between $63^{\circ}$ and $66^{\circ} \mathrm{N}$, southern West Greenland. Rapp. Grønlands geol. Unders. 85, 49-50.

Secher, K. \& Thorning, L. 1982: Detailed ground magnetic survey in the central part of the Sarfârtoq carbonatite complex, southern West Greenland. Rapp. Grønlands geol. Unders. 110, 32-38.

Sharma, P. V. 1973: Seismic activity and sediment thickness investigations by refraction soundings in Nûgssuaq, West Greenland. Rapp. Grønlands geol. Unders. 54, 22 pp.

Thorning, L. 1976: Aeromagnetic surveys in southern and central West Greenland between $63^{\circ}$ and $71^{\circ}$ N. Rapp. Grønlands geol. Unders. 80, 61-65.

Thorning, L. 1977: Continuation of the aeromagnetic surveys in southern and central West Greenland between $64^{\circ}$ and $72^{\circ}$ N. Rapp. Grønlands geol. Unders. 85, 34-37.

Thorning, L. 1978: Project EASTMAR: a new aeromagnetic survey of the continental shelf of eastern Greenland. Rapp. Grønlands geol. Unders. 90, 113-115.

Thorning, L. 1979: Ground magnetic investigations in the Godthåbsfjord region, southern West Greenland. Rapp. Grønlands geol. Unders. 95, 61-63.

Thorning, L. 1983: A magnetic and electromagnetic investigation of disseminated sulphide mineralization at 'Fossilik', central West Greenland. Rapp. Grønlands geol. Unders. 115, 37-38.

Thorning, L. 1984: Aeromagnetic maps of parts of southern and central West Greenland: acquisition, compilation and general analysis of data. Rapp. Gronlands geol. Unders. 122, $36 \mathrm{pp}$.

Thorning, L. 1985: Determination of ice-thickness by magnetic methods at Nordbogletscher, South Greenland. Rapp. Grønlands geol. Unders. 125, 112-114.

Thorning, L. \& Boserup, M. 1985: Geophysical field work in relation to mineral exploration programmes in South Greenland. Rapp. Grønlands geol. Unders. 125, 78-83.

Thorning, L., Bower, M., Hardwick, C. D. \& Hood, P. J.1984: Greenland ice cap aeromagnetic survey 1983: acquisition of high sensitivity total field and gradient magnetic data. Rapp. Grønlands geol. Unders. 120, 32-36.

Thorning, L., Bower, M., Hardwick, C. D. \& Hood, P. J. 1985: Greenland ice cap aeromagnetic survey 1984: reconnaissance lines in southern Greenland. Rapp. Grønlands geol. Unders. 125, 83-84.

Thorning, L., Jensen, L. B., Marcussen, C., Mielby, B. S. \& Petersen, S. A. 1978: Geophysical field work on selected aeromagnetic anomalies in central West Greenland. Rapp. Grønlands geol. Unders. 90, 38-42.

Thorning, L. \& Langel, R. A.: A new satellite magnetic anomaly map of Greenland based on MAGSAT data. Unpublished.

Weng, W. L. 1980: Preliminary Bouguer anomalies of western North Greenland. Rapp. Grønlands geol. Unders. 99, 153-154.

Zarudzki, E. F. K. 1980: Interpretation of shallow seismic profiles over the continental shelf in West Greenland between latitudes $64^{\circ}$ and $69^{\circ} 30^{\prime} \mathrm{N}$. Rapp. Grønlands geol. Unders. 100, 58-61.

Geological Survey of Greenland,

Oster Voldgade 10,

DK-1350 Copenhagen K,

Denmark. 